\title{
RESIDUES OF CARBOSULFAN AND ITS CARBOFURAN METABOLITES AND 3-HYDROXY-CARBOFURAN IN ORANGES ${ }^{1,2}$
}

\author{
MARCOS JOSÉ TREVISAN ${ }^{3}$, GILBERTO CASADEI DE BAPTISTA ${ }^{4}$, LUIZ ROBERTO PIMENTEL TREVIZAN ${ }^{4}$, \\ GERALDO PAPA ${ }^{5}$
}

\begin{abstract}
The objectives of this study were to evaluate the residues of the insecticide carbosulfan and its carbofuran metabolites and 3hydroxy-carbofuran in orange compartments (whole fruit, bagasse and juice) and comparison between the residual levels found in fruits with the maximum residue level and the safety interval established by the Brazilian legislation. Two field experiments were carried out, both with the following treatments: a-check; b-one application of $10 \mathrm{~g}$ of carbosulfan . $100 \mathrm{~L}^{-1}$ of water; c-one application with twice the rate applied in treatment b; $\mathrm{d}$-four applications with the same rate applied in treatment b. Samples were taken at (-1), zero, 1, 3, 7, 14, 21 and 28 days after the last or unique application. The quantitative determinations were done by gas chromatography technique, using a nitrogen-phosphorus detector. The carbosulfan metabolism to its carbofuran metabolite was rapid ( 3 days), being both analytes concentrated in the bagasse (peel + flavedo + albedo). However, the metabolism of carbofuran to 3-hydroxy-carbofuran was of low intensity or this metabolite was quickly dissipated. Carbosulfan residues and its metabolites did not penetrate into the fruit, thus not contaminating the juice. The use of the pesticide was adequate, with respect to fruit consumption, in relation to the Brazilian legislation.
\end{abstract}

Index terms: Citrus sinensis, metabolism, pesticide residues in citrus, maximum residue level, safety interval

\section{RESÍDUOS DE CARBOSSULFAN E DE SEUS METABÓLITOS CARBOFURAN E 3-HIDROXI-CARBOFURAN EM LARANJA}

\begin{abstract}
RESUMO - Os objetivos do estudo foram avaliar os resíduos do inseticida carbossulfan e de seus metabólitos carbofuran e 3-hidroxi-carbofuran em compartimentos (frutos inteiros, bagaço e suco) e a comparação entre os níveis residuais encontrados nos frutos com o limite máximo de resíduo e o intervalo de segurança estabelecidos pela legislação brasileira. Foram conduzidos dois experimentos de campo, ambos com os seguintes tratamentos: a - testemunha; b - uma aplicação de $10 \mathrm{~g}$ de carbossulfan. $100 \mathrm{~L}^{-1}$ de água; c - uma aplicação com o dobro da dosagem do tratamento b; $\mathrm{d}$ - quatro aplicações na dosagem do tratamento b. As amostras foram colhidas a: (-1); zero; $1 ; 3 ; 7 ; 14 ; 21$ e 28 dias após a última ou única aplicação. As determinações quantitativas foram feitas por técnica de cromatografia em fase gasosa, usando detector de nitrogênio-fósforo. O metabolismo de carbossulfan a seu metabólito carbofuran foi rápido (3 dias), sendo ambos os analitos concentrados no bagaço (casca+flavedo+albedo). Entretanto, o metabolismo de carbofuran a 3-hidroxi-carbofuran foi de baixa intensidade ou este metabólito foi rapidamente dissipado. Resíduos de carbossulfan e de seus metabólitos não penetraram no interior do fruto, não contaminando, assim, o suco. O uso do agrotóxico mostrou-se adequado, com respeito ao consumo da fruta, em relação à legislação brasileira.
\end{abstract}

Termos para indexação: Citrus sinensis, metabolismo, resíduos de agrotóxicos em citros, limite máximo de resíduo, intervalo de segurança.

\section{INTRODUCTION}

The development of the agriculture, the enlargement of the agricultural boundaries, the improvement of the food production technology, and mainly the demands of the new markets for better products both in quality and quantity has been made among others with intensive uses of fertilizers and pesticides for productivity warranty.

Brazil is the major orange juice producer and exporter in a worldwide basis, and citrus crops play an important role in national economy. Citrus groves cover an area of about 820 thousand hectares and yielded 460 millions of standard boxes with an exchange credit of US $\$ 900$ millions in 2002 (AGRIANUAL, 2003).

Citrus crops have important pest problems, including the citrus leprosis mite and the citrus rust mite (Gallo et al., 2002), for their control growers commonly use pesticides and among them the carbamate insecticide carbosulfan.

Studies on pesticide metabolism are an important issue, because even more toxic metabolites may possibly arise than the parent compound, what requires a more complete and wide toxicological evaluation of the applied products mainly under field conditions.

In the environment, carbosulfan is first metabolized to carbofuran, then to 3-hydroxy-carbofuran and thereafter to 3-ketocarbofuran (Tomlin, 1995). This is a special case in which a less toxic pesticide (carbosulfan, $\mathrm{DL}_{50} 250 \mathrm{mg} \cdot \mathrm{kg}^{-1}$ for rats) is transformed in a more toxic one (carbofuran, $\mathrm{DL}_{50} 8 \mathrm{mg} \cdot \mathrm{kg}^{-1}$ for the same species), after its application (Tomlin, 1995). It is believed that under field conditions the toxic effect of carbosulfan is mainly due to the transformation to its carbofuran metabolite.

The maximum residue level (MRL) established by the Brazilian legislation for carbosulfan does not take into account the sum of its metabolites as total toxic residues of this carbamate insecticide, although this should be properly considered.

Nigg et al. (1985) studied the dislodgeable residues of carbosulfan and its carbofuran, 3-hydroxy-carbofuran and 3-ketocarbofuran metabolites in leaves, fruits and soil, in an orange grove in Florida during the fall and the winter seasons. Carbosulfan and carbofuran dissipation was rapid in fruit surfaces in both experiments (34 folds in 3 days) during fall season; however it was significantly slower during winter (1.5 time in 3 days). In both periods persistence in soil was higher than that observed for fruits and leaves (2-3 folds in 8 days). The most important carbosulfan metabolite was carbofuran. Also, carbofuran was more persistent in orange leaves than the applied parent compound in both seasons.

Barba et al. (1995) studied in Spain, the kinetics of carbosulfan residue disappearance in peach after application of the insecticide as the commercial formulation of emulsifiable concentrate. Typically, degradation showed two steps: one corresponding to the degradation phase itself ( 0 to 28 days) with a half-life of 7.4 days; and the other corresponding to the persistence phase (28 to 57 days) with a half-life of 17.5 days. After 57 days from application residues did not exceed 0.2

\footnotetext{
${ }^{1}$ (Trabalho 163/2003). Recebido: 23/10/2003. Aceito para publicação: 02/08/2004. Part of the MS dissertation presented by the first author to the Graduate Program of Entomology of ESALQ/USP.

${ }^{2}$ Research work partly supported by FAPESP (Fundação de Amparo à Pesquisa do Estado de São Paulo).

${ }^{3}$ Departamento de Produção Vegetal, ESALQ/USP, 13418-900, Piracicaba-SP, Brasil, mjtrevis@ esalq.usp.br

${ }^{4}$ Departamento de Entomologia, Fitopatologia e Zoologia Agrícola, ESALQ/USP, 13418-900, Piracicaba-SP, Brasil, gcbaptis@esalq.usp.br , lrptrevi@esalq.usp.br

${ }^{5}$ Departamento de Fitossanidade, Engenharia Rural e Solos, FEIS/UNESP, Campus de Ilha Solteira, 15385-000, Ilha Solteira-SP, gpapa@ bio.feis.unesp.br.
} 
$\mathrm{mg} \cdot \mathrm{kg}^{-1}$ and ranged from $0.122 \mathrm{mg} \cdot \mathrm{kg}^{-1}$ up to $0.4 \mathrm{mg} \cdot \mathrm{kg}^{-1}$ during the harvesting time. The main metabolite carbofuran was not quantified above the limit of determination of the method $\left(0.004 \mathrm{mg} \cdot \mathrm{kg}^{-1}\right)$ during the period of study.

Varca et al. (1998) investigated the pesticide dissipation in a paddy rice crop associated with fish production. They found that carbosulfan was fastly converted to carbofuran in all rice eco-system components, except for the rice leaves where its occurrence as the original compound lasted 7 days. Carbofuran was the main metabolite with 30 days of permanence in the soil.

The objectives of this study were to evaluate carbosulfan residues and its carbofuran metabolites and 3-hydroxy-carbofuran in whole fruit, bagasse (peel + flavedo + albedo) and orange juice, as to embrace: the study of carbosulfan metabolism under field conditions, the alteration (reduction or augmentation) of the contamination by the residues in these substrates/compartments and comparison between the residual levels in fruits with the maximum residue level (MRL) and the safety interval established by the Brazilian legislation for this pesticide.

\section{MATERIAL AND METHODS}

\section{Experiments}

Two experiments were carried out both in a randomized complete block design with four treatments and three replications. Commercial carbosulfan was applied as a concentrate suspension at $200 \mathrm{~g}$ a.i. $\mathrm{L}^{-1}$, according to the following treatments: $\mathrm{A}-$ check; $\mathrm{B}$ - one application at the rate of $10 \mathrm{~g}$ of carbosulfan. $100 \mathrm{~L}^{-1}$ of water; $\mathrm{C}$ - one application at the rate of $20 \mathrm{~g}$ of carbosulfan. $100 \mathrm{~L}^{-1}$ of water; and D - four applications at the rate of $10 \mathrm{~g}$ of carbosulfan. $100 \mathrm{~L}^{-1}$ of water. Applications were performed using a motorized atomizer back sprayer.

Climatic data (temperature and rainfall) were monitored and recorded within the experimental areas with the purpose of relating them to residue levels and with carbosulfan metabolism.

Fruit samples were 20 units each, and were randomly taken from each plot, observing its spatial distribution in the plants in order to obtain a representative sample.

\section{Experiment 1}

Experiment 1 was set on August $13^{\text {th }}$, 2001, in an eight-yearsold orange grove, with cv "Valencia", spaced $8 \mathrm{~m}$ between rows and $5 \mathrm{~m}$ between plants, in Cordeirópolis County, State of São Paulo (SP), Brazil

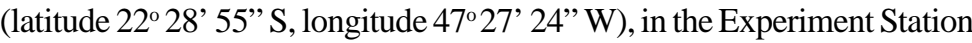
of Instituto Agronômico-Centro de Citricultura "Sylvio Moreira".

The experimental unit (plot) had two large, selected and healthy plants, and two plants separating plots from each other. The treatments were applied using 10 liters of insecticide suspension per plant, as recommended and enough to the complete watering of the trees.

The treatments were applied during the fructification period (fruit set/ripening): the first application of D treatment $(10 \mathrm{~g}$ of carbosulfan. $100 \mathrm{~L}^{-1}$, four applications) was performed on August $13^{\text {th }}$, 2001, followed by the others sprays at 7-days-intervals. Treatments B (10 g carbosulfan. $\left.100 \mathrm{~L}^{-1}\right)$ and $\mathrm{C}\left(20 \mathrm{~g}\right.$ carbosulfan. $\left.100 \mathrm{~L}^{-1}\right)$, one application, were applied together with the last treatment $\mathrm{D}$ spray.

The samples were collected at (-1), zero, 1, 3, 7, 14, 21 and 28 days after the last (or unique) application, occurring the first sampling on September $2^{\text {nd }}$ and the last one on October $1^{\text {st }}, 2001$; samples were immediately processed and homogenized, thereafter $400 \mathrm{~g}$ sub-samples were taken and stored at $-20^{\circ} \mathrm{C}$. In the overall, 96 samples were collected representing 4 treatments $\times 3$ replications x 8 samplings, in a total of 288 determinations for the three analytes.

\section{Experiment 2}

Experiment 2 was set on February $26^{\text {th }}, 2002$, in a 2.5 -years-old orange grove at São José farm, São Pedro County, SP, Brazil (latitude $22^{\circ}$
33' 45” S, longitude $47^{\circ}$ 56' 15”'W), cv. 'Pera Rio', planted in rows $7 \mathrm{~m}$ apart and $3 \mathrm{~m}$ between plants. Each plot had 8 shrub-like, well developed and healthy plants isolated from others plots by four plants. Every four plants were sprayed with 10 liters of the insecticide suspension, what was enough to complete plant watering (canopy) that resulted in about the same amount of pesticide used in Experiment 1.

The first application of D treatment $\left(10 \mathrm{~g}\right.$ carbosulfan. $100 \mathrm{~L}^{-1}$, four applications) occurred during fruit ripening, on February $26^{\text {th }}, 2002$, followed by the other sprays at 7-days-intervals. Treatment B (10 g carbosulfan. $\left.100 \mathrm{~L}^{-1}\right)$ and $\mathrm{C}\left(20 \mathrm{~g}\right.$ carbosulfan. $\left.100 \mathrm{~L}^{-1}\right)$, one application, were applied together with the last spray of treatment $\mathrm{D}$.

The samples were taken and processed in the same way as for Experiment 1, with the sampling starting on March $18^{\text {th }}$ and finishing on April $16^{\text {th }}, 2002$. Also, a total of 96 samples were collected. Due to the low contamination found in the whole fruit in Experiment 1, and wishing to study the possible concentration of the residues in the bagasse and their eventual penetration into the juice compartments, the samples were separated as to comprise 192, being 96 bagasse (peel + flavedo + albedo) and 96 juice samples for a total of 576 determinations performed. Thus, fruit units were cut in halves and the juice extracted in an appliance extractor; following, the bagasse was homogenized in a domestic electric mill; after that, $400 \mathrm{~g}$ sub-samples (or $400 \mathrm{~mL}$ juice) each were taken, and kept at $-20^{\circ} \mathrm{C}$

\section{Analytical methodology}

The analytical method was adapted from Andersson \& Palsheden (1998): the carbosulfan, carbofuran and 3-hydroxy-carbofuran residues were extracted with ethyl acetate; after that, an extract aliquot sample was concentrated by evaporation and re-suspended in an ethyl acetate/cyclohexane mixture. Then, the extract was cleaned up through gel permeation chromatography technique (GPC), followed by elution with the same mixture. After new concentration, the extract was diluted in acetone, and quantitatively determined by gas chromatography (ThermoQuest, Trace GC model), equipped with nitrogen-phosphorus detector, BPX-5 megabore chromatographic column ( $40 \mathrm{~m}$ long, $0.53 \mathrm{~mm}$ diameter and $1 \mu \mathrm{m}$ film thickness), and a HP workstation, Kayak XA model, software version A.06.03.

Analyses were made using $20 \mathrm{~g}$-homogenized samples (10 g bagasse, $10 \mathrm{~mL}$ juice), transferred to $100 \mathrm{~mL}$ Duran-Schott flasks to which $50 \mathrm{~mL}$ ethyl acetate and $10 \mathrm{~g} \mathrm{Na}_{2} \mathrm{SO}_{4}$ were added. After that, the mixture was homogenized in an Ultra-turrax device, during 2 minutes at 26,000 rpm and centrifuged during 5 minutes at 2,500 rpm. A $10 \mathrm{~mL}$-aliquot sample of the supernatant was transferred to $50 \mathrm{~mL}$ polypropylene tube and evaporated to dryness in water-bath under airflow, previously dried through silica gel filters.

The extract was cleaned up through gel permeation chromatography (GPC) and for that, the residues were re-suspended in $2 \mathrm{~mL}$ ethyl acetate/cyclohexane $(1 / 1, \mathrm{v} / \mathrm{v})$ mixture, thoroughly rinsing the tube walls and collecting the extract in a $15 \mathrm{~mL}$ centrifuge tube, which was put in a mini-shaker for 1 minute and under ultra-sound for another minute. After that, the extract was filtered through a $0.20 \mu$ mesh Millipore membrane by means of 5-mL hypodermic syringes, and transferred to GPC vials. Following, the extract was injected into the GPC that was operated with an $1 \mathrm{~mL} / \mathrm{min}$ ethyl acetate/cyclohexane flow, discarding the eluates during the 13 first minutes and collecting the cleaned extracts during the subsequent 2.5 minutes in a $15 \mathrm{~mL}$ centrifuge tube. After the addition of two drops of ethylene glycol, the tube was taken to a TurboVap LV evaporator until complete extract drying under a slight $\mathrm{N}_{2}$ flow at $40^{\circ} \mathrm{C}$.

The residues were re-suspended in exactly $2 \mathrm{~mL}$ acetone and transferred to gas chromatograph auto-sampler vials using Pasteurpipettes. The extract aliquot samples were injected into the gas chromatograph, mode splitless, programmed with a linear sloping temperature program. The equipment operation conditions were: injector temperature $=220^{\circ} \mathrm{C}$; column temperatures $=100^{\circ} \mathrm{C}$ (start), for 1 minute; ramp of $30^{\circ} \mathrm{C} \cdot \mathrm{min}^{-1}$ up to $280^{\circ} \mathrm{C}$ (5 minutes); detector temperature $=300^{\circ} \mathrm{C}$. 
The gas flows were: $\mathrm{He}$ (carrier) $=5 \mathrm{~mL} \cdot \mathrm{min}^{-1}, \mathrm{~N}_{2}$ (make up $)=20 \mathrm{~mL} \cdot \mathrm{min}$ ${ }^{1}, \mathrm{H}_{2}=3 \mathrm{~mL} \cdot \mathrm{min}^{-1}$ and air $=60 \mathrm{~mL} \cdot \mathrm{min}^{-1}$.

Under these conditions, the retention times were: carbofuran 6 minutes and 35 seconds; 3 -hydroxy-carbofuran 7 minutes and 20 seconds and carbosulfan 11 minutes.

The residues were calculated directly from the correspondent calibration curves for carbosulfan $\left(r^{2}=0.9957\right)$; carbofuran $\left(r^{2}=0.9938\right)$; and 3-hydroxy-carbofuran $\left(r^{2}=0.9984\right)$, previously plotted by comparison with standards (external standard), based on the analytical standard and sample masses and obtained from injections of 2, 5, 10,20 and $50 \mathrm{pg}$ of each compound into the chromatographic system.

\section{Analytical method validation}

The analytical method validation was confirmed with fortification and percent recoveries studies. For that, fruit samples were fortified as to obtain concentrations of $1,0.5,0.05,0.02$, and $0.01 \mathrm{mg} . \mathrm{kg}$ ${ }^{1}$ with determinations made in triplicates. Fifty-four samples were fortified corresponding to 6 levels (check included) x 3 analytes x 3 replications. In this way it was found the limit of quantitation (LOQ) of $0.05 \mathrm{mg} \cdot \mathrm{kg}^{-1}$ for all of them.. Recovery percentages were: carbosulfan $77-98 \%$; carbofuran 101-119\% and 3-hydroxy-carbofuran 71-108\%.

\section{Analysis of the results}

The data obtained allowed the calculations of same statistical parameters such as means, standard mean deviations and coefficients of variation; mean values were plotted in figure. The validation of the analytical method was based on the fortification studies and was considered satisfactory, due to recoveries of 70 to $120 \%$.

\section{RESULTSANDDISCUSSION}

Results indicated (Table 1) that the metabolism of carbosulfan residues to carbofuran, if whole fruits (Cordeirópolis) are considered, was rapid, since they were found only until in some 3-days-samples only, after the last or unique application, and not found even in those taken at (-1) day from treatment with multiple applications, which had already received 3 spray applications to the date. Similar results have already been reported by Nigg et al. (1985). On the other hand, residues of 3-hydroxy-carbofuran were not found in any sample $\left(<0.05 \mathrm{mg} . \mathrm{kg}^{-1}\right)$, thus indicating a low production of this metabolite, from carbofuran, or its quick disappearance.

The mild temperatures of September, 2001 in Cordeirópolis ( maximum and minimum daily average $=27.2^{\circ} \mathrm{C}$ and $14.4^{\circ} \mathrm{C}$, respectively) and the rainfall of $46 \mathrm{~mm}$ between the $7^{\text {th }}$ and $14^{\text {th }}$ sampling, are indicative that environment conditions had not any or very little influence on residue levels, since they were already below LOQ $\left(<0.05 \mathrm{mg} \cdot \mathrm{kg}^{-1}\right)$ at 7 days sampling.

The citrus fruits MRLs are established on whole fruit basis. As for carbosulfan, Brazilian legislation does not take into account the sum of its metabolites as total toxic residues of this insecticide, being 0.05 mg.kg-1 its MLR and 7days its safety interval (Agência Nacional de Vigilância Sanitária, 2003). Thus, it is evidenced that, even if the

TABLE 1 - Carbosulfan and carbofuran residues ( $m \pm$ s.d.)* in oranges

\begin{tabular}{|c|c|c|c|c|c|c|c|}
\hline \multirow[t]{3}{*}{ Treatments } & \multirow{3}{*}{$\begin{array}{l}\text { Days after } \\
\text { application }\end{array}$} & \multicolumn{6}{|c|}{ Residues in fruits $\left(\mathrm{mg} \cdot \mathrm{kg}^{-1}\right)$} \\
\hline & & \multicolumn{2}{|c|}{ Cordeirópolis (whole fruit) } & \multicolumn{4}{|c|}{ São Pedro (bagasse) } \\
\hline & & carbosulfan & carbofuran & carbos & ulfan & carbo & uran \\
\hline \multirow{8}{*}{ Check } & -1 & $<0.05$ & $<0.05$ & $<0$ & 05 & \multicolumn{2}{|c|}{$<0.05$} \\
\hline & 0 & $<0.05$ & $<0.05$ & $<0$. & & \multicolumn{2}{|c|}{$<0.05$} \\
\hline & 1 & $<0.05$ & $<0.05$ & $<0$. & & \multicolumn{2}{|c|}{$<0.05$} \\
\hline & 3 & $<0.05$ & $<0.05$ & $<0$. & & \multicolumn{2}{|c|}{$<0.05$} \\
\hline & 7 & $<0.05$ & $<0.05$ & $<0$. & & \multicolumn{2}{|c|}{$<0.05$} \\
\hline & 14 & $<0.05$ & $<0.05$ & $<0$. & & \multicolumn{2}{|c|}{$<0.05$} \\
\hline & 21 & $<0.05$ & $<0.05$ & $<0$. & & \multicolumn{2}{|c|}{$<0.05$} \\
\hline & 28 & $<0.05$ & $<0.05$ & $<0$. & & \multicolumn{2}{|c|}{$<0.05$} \\
\hline \multirow{8}{*}{$\begin{array}{l}10 \mathrm{~g} \text { a.i. } 100 \mathrm{~L}^{-1} \text { of } \\
\text { water } \\
\text { (one application) }\end{array}$} & -1 & $<0.05$ & $<0.05$ & $<0$. & & \multicolumn{2}{|c|}{$<0.05$} \\
\hline & 0 & $<0.05$ & 0.06 & 0.37 & 0.07 & 0.21 & 0.04 \\
\hline & 1 & $<0.05$ & $<0.05$ & 0.16 & 0.06 & 0.09 & 0.02 \\
\hline & 3 & $<0.05$ & $<0.05$ & 0.35 & 0.07 & 0.21 & 0.03 \\
\hline & 7 & $<0.05$ & $<0.05$ & 0.07 & 0.01 & 0.20 & 0.06 \\
\hline & 14 & $<0.05$ & $<0.05$ & $<0 . C$ & & 0.09 & 0.02 \\
\hline & 21 & $<0.05$ & $<0.05$ & $<0 . C$ & & 0 . & \\
\hline & 28 & $<0.05$ & $<0.05$ & $<0.0$ & & 0.06 & 0.01 \\
\hline \multirow{8}{*}{$\begin{array}{l}20 \mathrm{~g} \text { a.i. } 100 \mathrm{~L}^{-1} \text { of } \\
\text { water } \\
\text { (one application) }\end{array}$} & -1 & $<0.05$ & $<0.05$ & $<0.0$ & & \multicolumn{2}{|c|}{$<0.05$} \\
\hline & 0 & $0.17 \quad 0.10$ & 0.11 & 0.83 & 0.31 & 0.35 & 0.05 \\
\hline & 1 & $0.06 \quad 0.01$ & 0.05 & 0.42 & 0.05 & 0.28 & 0.02 \\
\hline & 3 & 0.05 & $<0.05$ & 0.42 & 0.02 & \multicolumn{2}{|c|}{$0.28 \quad 0.02$} \\
\hline & 7 & $<0.05$ & $<0.05$ & 0.09 & 0.02 & \multicolumn{2}{|c|}{$0.23 \quad 0.04$} \\
\hline & 14 & $<0.05$ & $<0.05$ & \multicolumn{2}{|c|}{$<0.05$} & 0.13 & 0.03 \\
\hline & 21 & $<0.05$ & $<0.05$ & \multicolumn{2}{|c|}{$<0.05$} & 0.08 & 0.02 \\
\hline & 28 & $<0.05$ & $<0.05$ & \multicolumn{2}{|c|}{$<0.05$} & \multicolumn{2}{|c|}{0.06} \\
\hline \multirow{8}{*}{$\begin{array}{c}10 \mathrm{~g} \text { a.i. } 100 \mathrm{~L}^{-1} \text { of } \\
\text { water } \\
\text { (four applications) }\end{array}$} & -1 & $<0.05$ & $\begin{array}{ll}0.07 & 0.01\end{array}$ & \multicolumn{2}{|c|}{$<0.05$} & 0.46 & 0.06 \\
\hline & 0 & 0.05 & 0.06 & 0.47 & 0.13 & 1.18 & 0.28 \\
\hline & 1 & 0.05 & $<0.05$ & 0.28 & 0.05 & 0.61 & 0.22 \\
\hline & 3 & $<0.05$ & 0.05 & 0.45 & 0.05 & 1.09 & 0.05 \\
\hline & 7 & $<0.05$ & $<0.05$ & 0.07 & 0.02 & 0.86 & 0.10 \\
\hline & 14 & $<0.05$ & $<0.05$ & \multicolumn{2}{|c|}{$<0.05$} & 0.51 & 0.13 \\
\hline & 21 & $<0.05$ & $<0.05$ & $<0$. & & 0.23 & 0.06 \\
\hline & 28 & $<0.05$ & $<0.05$ & $<0$. & & 0.15 & 0.05 \\
\hline
\end{tabular}

* average of three replications; s.d. = means \pm standard deviation 


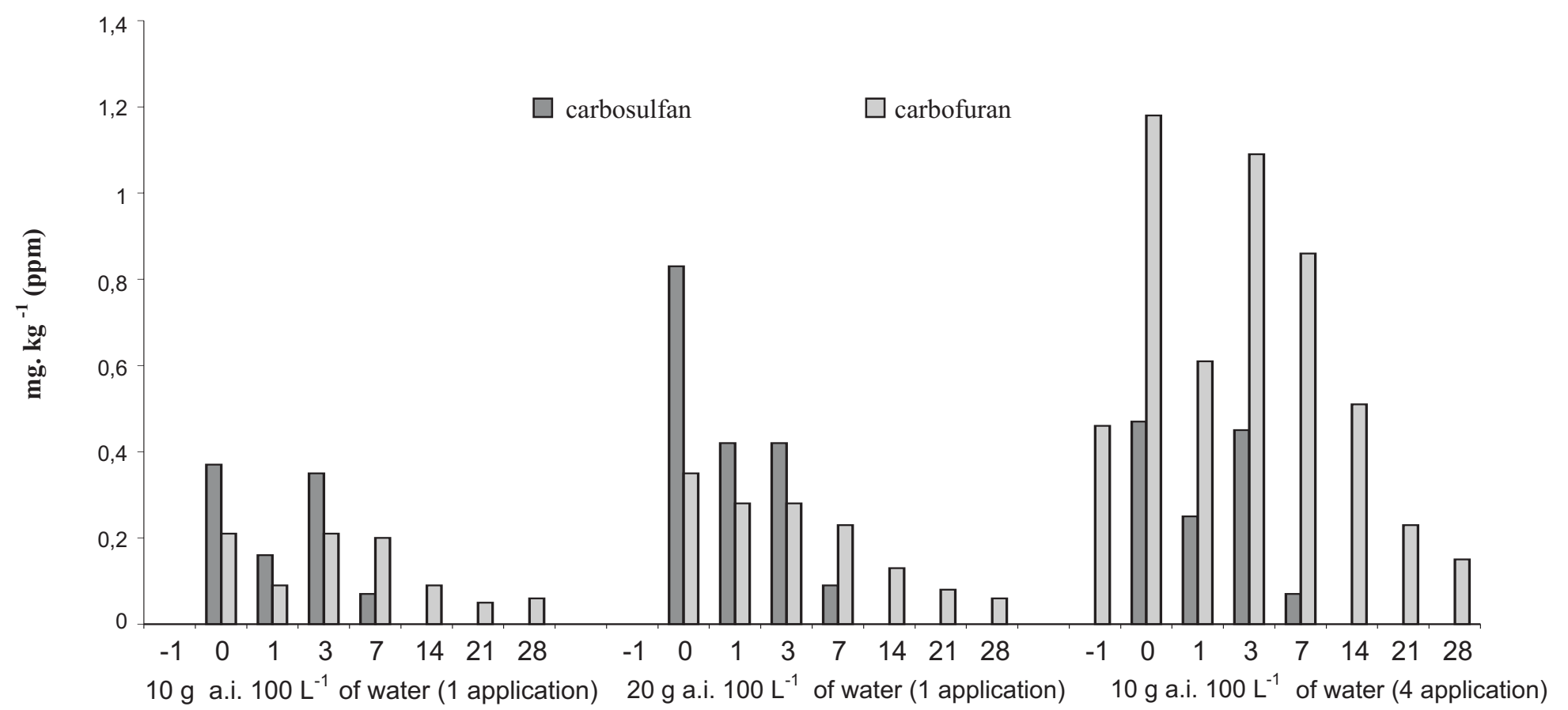

FIGURE 1 - Carbosulfan and carbofuran residues in orange bagasse (São Pedro)

metabolites are included, total toxic carbosulfan residues were below MRL at the end of safety interval and, consequently, fruits were proper to consumption.

Carbosulfan residues, as expected, were, indeed, higher in the bagasse (São Pedro) than in the whole fruit (Table 1, Figure 1), and they decreased rapidly (6-9 folds) during the sampling period, being not found $\left(<0.05 \mathrm{mg} \cdot \mathrm{kg}^{-1}\right)$ in samples collected after 7 days after the last or unique application, as a consequence of its conversion to carbofuran. Residues of this latter insecticide were found in all samples which had received carbosulfan field application, and in levels higher than this insecticide, particularly after 7 days and until the end of sampling period (2-11 folds), remaining in the bagasse at least for 28 days, with evidenced tendency of accumulation in treatment with multiple spray applications, and decreasing more slowly during this period, as compared with carbosulfan residues. This demonstrates intense carbosulfan metabolism to carbofuran and, as a result, the appearance of the residues of this latter insecticide in the bagasse, as found by Nigg et al. (1985) and Varca et al. (1998).

The residues of 3-hydroxy-carbofuran were found particularly in few samples of bagasse of the treatment with the double rate $(20 \mathrm{~g}$ a.i. $100 \mathrm{~L}^{1}$ of water); however, in very low levels $\left(0.05-0.09 \mathrm{mg} \cdot \mathrm{kg}^{-1}\right)$. Thus, it is evidenced its low production from carbofuran or its fast dissipation, like it was also found by Trevizan et al.(2002), when analyzing residues of such carbamate esters in rice paddy waters.

Similarly, the mild temperatures prevailing during the sampling period from March to April/2002, in São Pedro (maximum and minimum daily average $=28.9^{\circ} \mathrm{C}$ and $17.7^{\circ} \mathrm{C}$, respectively) and the rainfall of $38 \mathrm{~mm}$ after the $8^{\text {th }}$ day, had very little or none influence on the residues found.

No residues of any analyte in all 96 orange juice samples were found, indicating none or very low penetration (non detectable, $<0.05$ mg. $\mathrm{kg}^{-1}$ ) into the juice compartments. This shows that the bagasse components, peel, flavedo and albedo, are efficient barrier against juice contamination, which uses as food source may, thus, be considered safe.

\section{CONCLUSIONS}

The metabolism of the insecticide carbosulfan to its carbofuran metabolite in oranges is rapid with dissipation of both pesticides in 3 days. Their residues concentrate in the bagasse (peel + flavedo + albedo), not penetrating into fruit interior, thus not contaminating the juice. Carbosulfan insecticide, used in citrus crops according to good agricultural practices, is adequate to fruit consumption in compliance with the Brazilian pesticide residue legislation.

\section{ACKNOWLEDGEMENTS}

The authors acknowledge the FAPESP (Fundação de Amparo à Pesquisa do Estado de São Paulo) for the financial support and the Instituto Agronômico (Centro de Citricultura Sylvio MoreiraCordeirópolis, SP, Brazil), for the help in the field experimentation.

\section{REFERENCES}

AGÊNCIANACIONAL DE VIGILÂNCIA SANITÁRIA. Toxicologia: monografia de produtos agrotóxicos; carbosulfan. Available in: < ht t p ://ww w. anvis a.gov.br/A GROSIA/asp/ frm_dados_ingrediente.asp?iVarAux $=1 \&$ Codling=77.> Access in 10 out 2003.

AGRIANUAL 2002: anuário da agricultura brasileira. São Paulo: FNP Consultoria \& Comércio, 2003, p. 310.

ANDERSSON, A.; PALSHEDEN, H. Multi-residue method for analysis of pesticides in fruit and vegetables using ethyl acetate extraction, GPC clean-up and GC determination. In: NATIONAL FOOD ADMINISTRATION. Pesticide analytical methods in Sweden. Uppsala, 1998. pt., 1, p. 9-41 (Rapport 17/98).

BARBA, A.; NAVARRO-GARCIA, S.; CAMARA, M.A.; MOLINABUENDIA, J. Disappearance of carbosulfan residues in peaches. Pesticide Science, v. 43, n. 4, p. 317-320, 1995.

GALLO, D.; NAKANO, O.; SILVEIRANETO, S.; CARVALHO, R.P.L.; BAPTISTA, G.C.de; BERTIFILHO, E.; PARRA, J.R.P.;ZUCCHI, R.A.; ALVES, S,B.; VENDRAMIN, J.D.; MARCHINI, L.C.; LOPES, J.R.S.; OMOTO, C. Entomologia Agrícola. Piracicaba: FEALQ, 2002.920p.

NIGG, H.N.; STAMPER, J.H.; KNAAK, J.B. Leaf, fruit, and soil surface residues of carbosulfan and its metabolites in Florida citrus groves. Journal of Agricultural and Food Chemistry, v. 32, n. 1, p. 80-85, 1985.

TOMLIN, C. The pesticide manual. 10.ed. Cambridge: The Royal Society of Chemistry, 1995. $1341 \mathrm{p}$.

TREVIZAN, L.R.P.; MATTOS, M.L.; MARTINS, J.F. da S.; BAPTISTA, G.C. de; MELLO, M.; DIAS, R.A. Carbofuran and 3-hydroxycarbofuran residues in irrigation water of a rice ecosystem in Southern Brazil. In: INTERNATIONALCONGRESS ON THE CHEMISTRY OF PLANT PROTECTION, 10., Basel. Book of Abstracts: v. 2, p. 62. VARCA,L.M.;TEJADA,A.W.; KENNEDY, I.R.; SKERRIT,J.H.; HIGHLEY, E. Dissipation of pesticides in rice paddy in the Philippines. ACIAR: Proceedings Series, Canberra, v. 85, n. 17-19, p. 140-148, 1998. 